\title{
Concepts and measures of patient empowerment: a comprehensive review
}

\author{
Del concepto de empoderamiento del paciente a los \\ instrumentos de medida: una revisión integrativa \\ Do conceito de empoderamento do paciente aos instrumentos \\ de medição: uma revisão integrativa
}

Paloma Garcimartín Cerezo ${ }^{1,2}$, Maria-Eulália Juvé-Udina ${ }^{3,4}$, Pilar Delgado-Hito ${ }^{3,4}$

How to cite this article:

Cerezo PG, Juvé-Udina ME, Delgado-Hito P. Concepts and measures of patient empowerment: a comprehensive review. Rev Esc Enferm USP. 2016;50(4):664671. DOI: http://dx.doi.org/10.1590/S0080-623420160000500018

\footnotetext{
${ }^{1}$ Universidad Pompeu Fabra, Escuela Superior de Enfermería del Mar, Barcelona, España

${ }^{2}$ Instituto Hospital del Mar de Investigaciones Médicas, Grupo de Investigación Biomédica en Enfermedades del Corazón, Barcelona, España.

${ }^{3}$ Universidad de Barcelona, Escuela Universitaria de Enfermería, Barcelona, España.

${ }^{4}$ Instituto de Investigación Biomédica de Bellvitge, Barcelona, España.
}

\begin{abstract}
Objective: Analyze the definitions and dimensions of empowerment. Identify the strengths and weaknesses of empowerment measures based on the conceptual model. Method: This was a comprehensive literature review of publications on the MEDLINE and Cumulative Index to Nursing and Allied Health Literature (CINAHL) databases. Results: Twenty-nine articles were selected. Seventeen definitions and seven dimensions of empowerment, and 10 empowerment measures were selected. Empowerment can be seen as an enabling process involving a shift in the balance of power, or as an outcome of this process. The dimensions reflect outcome indicators, such as participation in decisionmaking and control, and process indicators, such as knowledge acquisition and coping skills. Six of the tools analyzed by this study could be said to provide a robust measure of patient empowerment. Conclusion: we propose a definition of empowerment that helps to deepen understanding of the term and, therefore, its operationalization.
\end{abstract}

\section{DESCRIPTORS}

Patient Participation; Power; Self Efficacy, Decision Making; Personal Autonomy; Review. 


\section{INTRODUCTION}

In 2012, the World Health Organization's (WHO) Regional Office for Europe unveiled Health 2020(1), which sets out strategic directions and priority areas for European policy action for health and well-being up to 2020. One of the specific objectives of the framework is citizen and $\mathrm{pa}^{-}$ tient empowerment. The report regards empowerment and patient-centered care as key elements for improving health outcomes, user satisfaction with health care, communication between patients and health professionals, bringing about better adherence to treatment regimes, and ensuring the efficient use of primary health resources.

The concept of empowerment is employed in a wide range of contexts. In the sphere of health, the expression has been adopted primarily as a guiding basis for health promotion approaches and, in recent years, as a strategy for the management of chronic conditions. However, although there is broad consensus on its importance and its multidimensional nature, a universally accepted definition of the concept, its dimensions and its operationalization does not exist, thus giving rise to a variety of different measures of empowerment ${ }^{(2-5)}$.

The main purpose of this article is to analyze the different definitions and dimensions of the concept of empowerment that appear in the literature in order to identify differences and similarities and propose a single definition that embraces their essential characteristics. The secondary objective of this work is to identify the strengths and weaknesses of the tools designed to measure empowerment based on the conceptual model.

\section{METHOD}

A review of the literature on empowerment was undertaken in four stages (Figure 1). The first stage consisted of a search of the MEDLINE and CINAHL (Cumulative Index to Nursing and Allied Health Literature) databases. The Medical Subject Headings (MeSH) controlled vocabulary was initially adopted for the search of MEDLINE. However, the concept empowerment is a descriptor in the $\mathrm{MeSH}$ and refers to "Power (Psychology)" and "Patient Participation", and thus it was decided to use an ad hoc strategy using the keyword "Patient Empowerment" together with another descriptor "Chronic Disease" and the Boolean Operator AND. Language (English) was used as a limit. No time limit was added.

Controlled vocabulary was also used for the search of the CINAHL database, where empowerment is a Subject Heading. A first search was therefore carried out using the keyword "Patient Empowerment" and language (English), study population (adults) and peer-reviewed as limits, whereby 86 results were obtained. A second search was carried out combining "Patient Empowerment" AND "Chronic Disease", which gave rise to three results.

The searches resulted in a total of 137 articles, which was reduced to 126 after excluding repeated articles.

The second stage consisted of a title and abstract review using the following inclusion criteria: titles including at least one of the terms empowerment, self-efficacy, self-management, self-care, patient participation, patient engagement, patient involvement, expert patient, shared decision-making, and health literacy; abstracts mentioning the term empowerment or referring to a review of the concept or the design of questionnaires or measures of patient empowerment. Articles that did not have an abstract were excluded. A total of 45 articles were selected for the next stage.

In stage three, the full text of each selected article was reviewed. Those articles that provided a definition of the concept, illustrated its relationships with other concepts or outlined the dimensions of the main concept and proposed empowerment measuring tools were selected, resulting in a final simple of 29 papers.

The reviews conducted in the second and third stages were carried out by independent reviewers, resulting in a high level of concordance $(\kappa$-index $>0.8)$. Any discrepancies between reviewers were resolved by consensus.

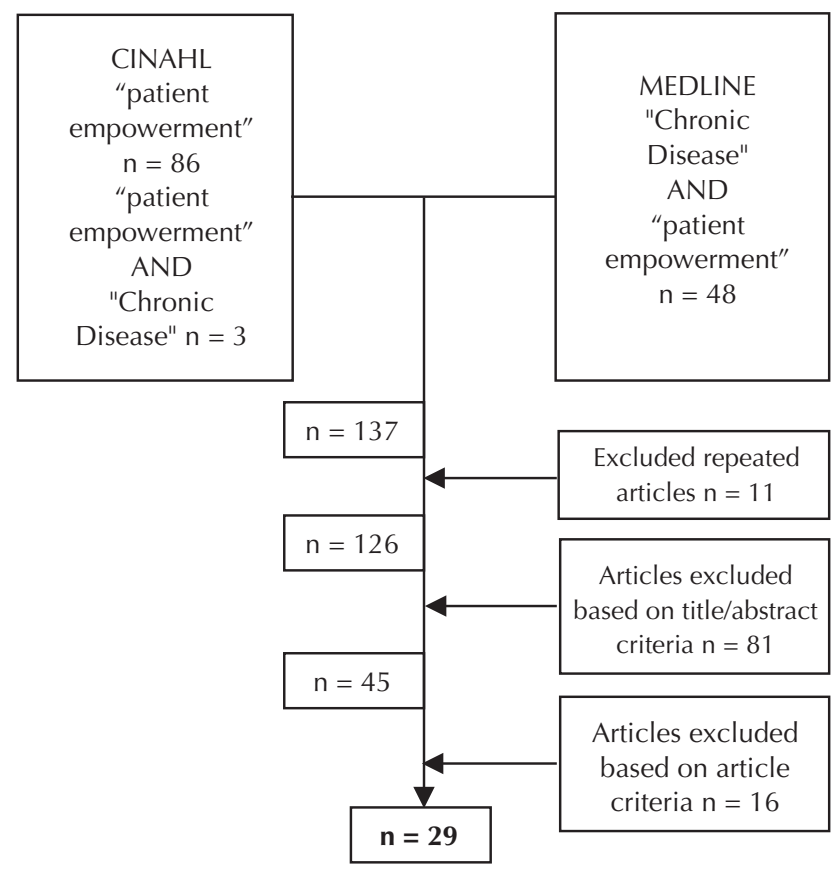

Figure 1 - Number of articles found on the databases, descriptors, criteria and sample selected for comprehensive review Barcelona, Spain, 2015.

The Evaluating the Measurement of Patient-Reported Outcomes (EMPRO) ${ }^{(6)}$ tool was used to identify the strengths and weaknesses of empowerment measuring tools based on the recommendations of Medical Outcomes Trust. The EMPRO covers eight key attributes: conceptual model, reliability, validity, responsiveness, interpretability, burden, modes of administration, and cross-cultural adaptation. An approximate version of the tool was used to evaluate the conceptual model since the present review only considered whether each tool provided a definition of the concept of empowerment and outlined its dimensions, rather than other assessment criteria, such as the participation of the target population in defining instrument content, the variability 
of the scale within the population, justifying the scale to measure empowerment, and the basis for calculating scores.

\section{RESULTS}

Seventeen definitions ${ }^{(7-23)}$ (Chart 1) and seven dimensions $^{(9,14,24-28)}$ of empowerment (Chart 2), and 10 empowerment measures ${ }^{(9,13,24,29-35)}$ (Chart 3 ) were selected.

The analysis showed that the concept of empowerment has been broadly used in the health sciences field, especially over the last 10 years. The majority of the publications studied trace the history of the concept back to pedagogy and community psychology ${ }^{(36-37)}$. This section is therefore structured into subsections: the first section outlines the history and evolution of the term, while the second contextualizes the concept within the health sciences field and outlines the different definitions of the term and empowerment measures.

\section{EMPOWERMENT WITHIN OTHER DISCIPLINES: PEDAGOGY TO PSYCHOLOGY}

One of the earliest references to the concept of empowerment was within the context of Paulo Freire's philosophy of emancipatory education ${ }^{(8,20)}$, in which empowerment is seen as a response to oppression and social inequality. Later, the concept was explored within community psychology, critical social theory, gender studies, rural economy and finally in health education and promotion ${ }^{(1,35)}$. Regardless of the disciplinary context in which it is used, the literature contains a wide range of meanings, definitions and interpretations of the term, thus transforming empowerment into a multidimensional concept.

One of the characteristics of the concept when viewed through the lens of psychology is that empowerment is an attribute of the community and not the individual. Authors differentiate between empowerment and concepts such as personal agency, self-efficacy, autonomy, self-determination, personal control, self-regulation, all of which have a generally equivalent meaning. The latter characteristics are considered individual attributes, and one can only talk of empowerment when these processes have an impact on the community, that is, when individuals actively participate in the community or organization ${ }^{(38-39)}$.

\section{EMPOWERMENT WITHIN THE HEALTH SCIENCES: HEALTH PROMOTION AND MANAGEMENT}

When applied to the field of health, the concept of empowerment is diversely used and remains contested. Initially, it was adopted as the backbone of health promotion and later used as a way of increasing patient autonomy and participation in making decisions related to their health. Finally, with the increase in chronic diseases, empowerment began to be used as a strategy to ensure that patients participate in and take responsibility for their health care in order to improve health outcomes and control health expenditure ${ }^{(7)}$.

The $\mathrm{WHO}^{(1)}$ defines empowerment as "a process through which people gain greater control over decisions and actions affecting their health, and as such individuals and communities need to develop skills, have access to information and resources, and the opportunity to participate in and influence the factors that affect their health and well-being".

\section{DeFINITION AND DIMENSIONS}

Certain characteristics that are inherent in the concept of empowerment are common to all the definitions found in the review (Chart 1): empowerment can be seen as an enabling process involving a shift in the balance of power, or as an outcome of this process.

Chart 2 illustrates topics found in the literature that we have classified as dimensions. It should be noted however that the other writers have employed different terms such as themes ${ }^{(13,19,40)}$, elements ${ }^{(22)}$, characteristics ${ }^{(17)}$ domains $^{(33)}$, and principles $^{(10)}$.

Chart 1 - Definitions of empowerment taken from the review - Barcelona, Spain, 2015.

\begin{tabular}{|c|c|}
\hline Definitions & References \\
\hline $\begin{array}{l}\text { A process of communication and education between professionals and patients, in which knowledge, } \\
\text { values and power are shared, which is seen as a process of personal transformation. }\end{array}$ & Aujoulat et al., $2007^{(7)}$ \\
\hline $\begin{array}{l}\text { The empowerment viewpoint conceives patients as self-determining agents with some control over their } \\
\text { own health. }\end{array}$ & McAllister et al., $2012^{(8)}$ \\
\hline $\begin{array}{l}\text { A process and outcome arising from communication between health care professionals and patients in- } \\
\text { volving the sharing of resources over information relating to illness, which enhances the patient's feelings } \\
\text { of control, self-efficacy, coping abilities and ability to effect change over their condition. }\end{array}$ & Small et al., $2013^{(9)}$ \\
\hline $\begin{array}{l}\text { Empowerment applied to health is the degree of choice, influence and control held by patients over treat- } \\
\text { ment, the disease and their relationship with health professionals. }\end{array}$ & Anderson et al., $2010^{(10)}$ \\
\hline $\begin{array}{l}\text { A process and outcome through which patients gain self-confidence and self-efficacy in order to actively } \\
\text { participate in their own health care and, ultimately, exercise power over decision-making concerning } \\
\text { their treatment. }\end{array}$ & Aslani, 2013 \\
\hline $\begin{array}{l}\text { Empowerment reflects a type of support that enables and motivates people to take the necessary steps to } \\
\text { manage and improve their health in a self-directed manner. }\end{array}$ & Bann et al., 2010 \\
\hline $\begin{array}{l}\text { It is the capacity shown by patients with chronic disease to accept their illness and to develop and use } \\
\text { specific coping strategies in order to regain a sense of control. }\end{array}$ & Bulsara et al., 2006 ${ }^{(13)}$ \\
\hline $\begin{array}{c}\text { An empowered patient is able to report changes, develop self-care activities, has the necessary skills and } \\
\text { capacity to develop coping strategies and promote self-management independently and feels in control of } \\
\text { his/her own life. }\end{array}$ & Fotoukian et al., $2014^{(14)}$ \\
\hline
\end{tabular}


...continuation

\begin{tabular}{|c|c|}
\hline Definitions & References \\
\hline $\begin{array}{l}\text { It is gaining the motivation and capacity (skills and knowledge) that patients can use to participate in } \\
\text { decision-making, thus creating the opportunity to shift the balance of power in their relationship with } \\
\text { health professionals. }\end{array}$ & Fumagalli et al., $2015^{(15)}$ \\
\hline $\begin{array}{l}\text { Empowerment is the process of recognizing, promoting, and enhancing people's abilities to meet their } \\
\text { own needs, solve their own problems, and mobilize the necessary resources in order to feel in control of } \\
\text { their own lives. }\end{array}$ & Gibson, $1991^{(16)}$ \\
\hline $\begin{array}{l}\text { It is power that is actualized through a beneficial relationship of mutual trust and respect for autonomy } \\
\text { that develops within a dynamic and patient-centered process. }\end{array}$ & Jerofke, $2013^{(17)}$ \\
\hline $\begin{array}{l}\text { Patient empowerment is achieved when there is an equitable or fair distribution of knowledge, and the } \\
\text { patient is involved in a shared decision-making process. }\end{array}$ & McWilliam et al., $2009^{(18)}$ \\
\hline Empowerment enables patients to gain control over their health. & $\mathrm{O}^{\prime}$ Cathain et al., $2005^{(19)}$ \\
\hline $\begin{array}{l}\text { A process involving a helping relationship that enables people to take control and make decisions about } \\
\text { their lives. }\end{array}$ & Rodwell, $1996^{(20)}$ \\
\hline $\begin{array}{l}\text { A process in which nurses collaborate with patients towards achieving the goal of disease self-manage- } \\
\text { ment; this implies that patients actively participate in their care. }\end{array}$ & Shearer et al., $2007^{(21)}$ \\
\hline $\begin{array}{l}\text { A collaborative approach in which health professionals help patients acquire the knowledge necessary to } \\
\text { make informed decisions and whose outcome is a patient who is responsible for the management of his/ } \\
\text { her illness. }\end{array}$ & Wentzer et al., $2013^{(22)}$ \\
\hline $\begin{array}{l}\text { Empowerment is the process of people obtaining the knowledge and skills that enables them to become } \\
\text { active partners with professionals in making informed decisions and choices about their own treatment } \\
\text { and care and of enabling communities to exert informed influence on the health system. }\end{array}$ & $\begin{array}{l}\text { Farrel \& Gilbert, } 1996(\text { cited } \\
\text { by Boudioni et al., 2012) }\end{array}$ \\
\hline
\end{tabular}

Source: authors' own elaboration, Barcelona, Spain, 2015.

Chart 2 - Dimensions of empowerment found by the review - Barcelona, Spain, 2015.

\begin{tabular}{|c|c|}
\hline Dimensions & References \\
\hline Participation in decision-making & $\begin{array}{l}\text { Small et al., 2013(9) } \\
\text { Fotoukian et al., 2014 } \\
\text { Ouschan et al., 2000 } \\
\text { Salmon et al., } 2004^{(28)}\end{array}$ \\
\hline Gaining control & $\begin{array}{l}\text { Small et al., 2013 } \\
\text { Fotoukian et al., 2014 } \\
\text { Ouschan et al., 2000 } \\
\text { Aujoulat et al., 2008 } \\
\text { Oh et al., 2012 } \\
\text { Salmon et al., 2004 } \\
\text { Sald }\end{array}$ \\
\hline Knowledge acquisition & $\begin{array}{l}\text { Aghili et al., 2013(24) } \\
\text { Ouschan et al., 2000 } \\
\text { Aujoulat et al., 2008 }\end{array}$ \\
\hline Coping skills & $\begin{array}{l}\text { Fotoukian et al., 2014 } \\
\text { Aghili et al.,2013 } \\
\text { Salmon et al., 2004 } \\
\text { (28) }\end{array}$ \\
\hline A positive attitude & Salmon et al., 2004(28) \\
\hline Sense of meaning to patients' experience with disease & Aujoulat et al., 2008(26) \\
\hline Motivation & Oh et al., $2012^{(27)}$ \\
\hline Trust & Oh et al., $2012^{(27)}$ \\
\hline Self-care & $\begin{array}{l}\text { Fotoukian et al., 2014(14) } \\
\text { Aghili et al., 2013 }\end{array}$ \\
\hline Sharing and capacity building & Small et al., $2013^{(9)}$ \\
\hline
\end{tabular}

Source: authors' own elaboration, Barcelona, Spain, 2015

\section{EMPOWERMENT MEASURES}

Ten empowerment measures were selected from the literature. The context in which these tools were applied and the operationalized constructs are described in Chart 3. Four tools were developed in the United States ${ }^{(29,31,33-34)}$, four in Great Britain $^{(9,30,32,35)}$, one in Australia ${ }^{(13)}$, and one in $\operatorname{Iran}^{(24)}$.
All but one of the tools ${ }^{(31)}$ are setting (primary health care $^{(9,32)}$ and hospital care $\left.{ }^{(30)}\right)$ or condition-specific. With respect to the condition-specific tools, one addressed mental health ${ }^{(33)}$, two diabetes ${ }^{(24,29)}$, two cancer ${ }^{(13,34)}$, and one clinical genetics ${ }^{(35)}$. One of the tools ${ }^{(34)}$ addressed two levels of specificity since it assessed cancer patients in virtual spaces. 
Chart 3 - Measures of empowerment found in the reviewed articles - Barcelona, Spain, 2015.

\begin{tabular}{|c|c|c|c|}
\hline Measure & Context & Dimensions measured & Reference \\
\hline $\begin{array}{l}\text { Patient empowerment in } \\
\text { long-term conditions }\end{array}$ & $\begin{array}{l}\text { Specific: primary care and } \\
\text { patients with chronic diseases }\end{array}$ & $\begin{array}{c}\text { Positive attitude and sense of control, knowledge and } \\
\text { confidence with respect to decision-making, sharing } \\
\text { and enabling others. }\end{array}$ & $\begin{array}{l}\text { Small et al., } \\
2013^{(9)}\end{array}$ \\
\hline $\begin{array}{l}\text { Patient Empowerment } \\
\text { Scale (PES) }\end{array}$ & Specific: cancer & Coping strategies and self-efficacy. & $\begin{array}{l}\text { Bulsara et al. } \\
\qquad 2006^{(13)}\end{array}$ \\
\hline $\begin{array}{l}\text { Diabetes empowerment } \\
\text { questionnaire }\end{array}$ & Specific: diabetes & Knowledge, self-care, coping. & $\underset{2013^{(24)}}{\text { Aghili et al., }}$ \\
\hline $\begin{array}{l}\text { Diabetes Empowerment } \\
\text { Scale (DES) }\end{array}$ & Specific: diabetes & $\begin{array}{l}\text { Managing the psychosocial aspects of disease } \\
\text { (self-management and coping), openness to change, } \\
\text { ability to define and set objectives. }\end{array}$ & $\begin{array}{l}\text { Anderson et al. } \\
\qquad 2000^{(29)}\end{array}$ \\
\hline $\begin{array}{l}\text { Patient Empowerment Scale } \\
\text { (PES) }\end{array}$ & Specific: hospital care & $\begin{array}{l}\text { Identification of activities that illustrate } \\
\text { empowerment and disempowerment in relation } \\
\text { to the nurse/patient relationship. }\end{array}$ & $\begin{array}{l}\text { Faulkner, } \\
2001^{(30)}\end{array}$ \\
\hline $\begin{array}{l}\text { Patient Activation } \\
\text { Measure (PAM) }\end{array}$ & Generic & $\begin{array}{l}\text { Skills, knowledge, and beliefs needed by patients to } \\
\text { self-manage, collaborate with healthcare providers } \\
\text { and maintain their health. }\end{array}$ & $\begin{array}{l}\text { Hibbard et al. } \\
2004^{(31)}\end{array}$ \\
\hline $\begin{array}{l}\text { Patient Enablement } \\
\text { Instrument (PEI) }\end{array}$ & Specific: primary care & Aspects of perceived control over illness. & $\begin{array}{l}\text { Howie et al. } \\
1998^{(32)}\end{array}$ \\
\hline The Empowerment Scale (ES) & Specific: mental health & $\begin{array}{l}\text { Self-efficacy, perceived power, optimism-control over } \\
\text { the future, and community activism. }\end{array}$ & $\begin{array}{l}\text { Rogers et al. } \\
1997^{(33)}\end{array}$ \\
\hline $\begin{array}{l}\text { CIDES: Cyber Info-Decisional } \\
\text { Empowerment Scale }\end{array}$ & $\begin{array}{l}\text { Specific: cancer patients who } \\
\text { manage the disease through a } \\
\text { network }\end{array}$ & Knowledge, participation, decision-making. & Seçkin, $2011^{(34)}$ \\
\hline $\begin{array}{l}\text { Genetic Counselling } \\
\text { Outcome Scale }\end{array}$ & Specific: clinical genetics & $\begin{array}{l}\text { Perceived personal control (decisional and behavioral } \\
\text { control), hope and emotional regulation. }\end{array}$ & $\begin{array}{l}\text { McAllister et al. } \\
2011^{(35)}\end{array}$ \\
\hline
\end{tabular}

Source: Authors' own elaboration, Barcelona, Spain, 2015.

\section{DISCUSSION}

\section{Definition AND DIMENSIONS}

With respect to the first definition in terms of chronological order ${ }^{(12)}$, which regards empowerment as a social process of recognizing, promoting, and enhancing people's abilities to meet their own needs, solve their own problems, and mobilize the necessary resources in order to feel in control of their own lives, it can be observed that it contains three characteristics that are present in other definitions: for empowerment to occur, patients must have prior abilities ${ }^{(9,12)}$, and empowerment is both a process ${ }^{(3,5,7-9,11,13,16-19)}$ and outcome ${ }^{(3-11,13-19)}$. With respect to prior abilities, only one author ${ }^{(9)}$ highlights which abilities help patients to accept the disease.

With regard to process, the majority of authors regard empowerment as a communicative process that is developed between health professionals and patients ${ }^{(7,9)}$, involving helping partnerships ${ }^{(20,23)}$, a collaborative ${ }^{(21-22)}$ patient-centered approach ${ }^{(17)}$, and fair and equal relationships ${ }^{(18)}$. The process should be guided by exchange of information involving knowledge and skill sharing ${ }^{(9,14-15,22,26)}$, coping strategies $^{(9,13)}$, and should include motivational elements ${ }^{(12,15)}$.

For the majority of authors, self-efficacy is considered an outcome of empowerment, while some $e^{(11,14)}$ suggest that it is acquired during the process and that it is a necessary element for patient participation in decision-making, which is seen as the final outcome of empowerment.

Certain authors suggest that the outcome of empowerment are changes in the patient's condition ${ }^{(7,9,21)}$, while others propose that the ultimate goal of empowerment is patient self-management ${ }^{(8,12,14,21-22)}$, self-efficacy ${ }^{(8-9)}$, self-care $^{(14)}$, control over the situation ${ }^{(8-9,13,16,19,20)}$, participation in decisionmaking ${ }^{(10-11,18,20,22)}$, and shifting the balance of power in health professional-patient relationships ${ }^{(15)}$.

Only one author ${ }^{(23)}$ considers empowerment at both the individual and community level, suggesting that an empowered patient can exert influence on the health system.

The dimensions reflect outcome indicators taken from the definitions, such as participation in decision-making and control, and process indicators expressed in terms of results, such as knowledge acquisition and coping skills.

Only one author ${ }^{(9)}$ incorporates sharing and enabling others, which is used along the same lines as community psychology. Other authors ${ }^{(13,22)}$ highlighted the importance of sharing the experience of the illness with peers in relation to feeling "more powerful", though did not refer to this as a dimension.

Self-efficacy as an outcome of the process of empowerment is one of the most frequently used concepts in the definitions; however, contrary to the concept of control and participation in decision-making, the term is not referred to as a dimension. This could be due to the fact that, despite being contextualized at different levels, efficacy and empowerment are overlapping concepts that have very similar attributes. Self-efficacy is seen as a concept employed at individual level, linked to personal levels of performance, and which has a clearly psychological component $^{(41)}$, while empowerment has psychological, social and political elements and is used to describe personal variables, care practices and the characteristics of the system ${ }^{(4,33,36)}$.

\section{MeAsuring TOOls}

Given that the key concept was patient empowerment, only nine out of the 10 abovementioned measures were examined 
in order to evaluate the conceptual model. Seven tools provide a definition of the concept being evaluated, five define the concept of empowerment ${ }^{(9,13,24,29,35)}$, one the concept of enablement $^{(32)}$, and one activation ${ }^{(31)}$. Based on the definitions and dimensions suggested by the authors, the latter two concepts may be considered synonyms of empowerment.

Two tools ${ }^{(9,24)}$ outline the dimensions of the concept and its corresponding indicators. Others describe what could be considered dimensions, but which the authors term as domains ${ }^{(33)}$, principles $^{(29)}$, themes ${ }^{(13,31)}$, or concepts ${ }^{(35)}$.

For the purpose of the analysis, all were considered dimensions regardless of the terminology used for the operationalization, since the review showed that these terms were repeated in various measures, as shown in Chart 4.

Based on this criterion, the following tools could be said to provide a robust measure of patient empowerment: DES-28, PAM, PES2, GCOS-24, Patient Empowerment in long-term conditions, and the Diabetes empowerment questionnaire.

\section{CONCLUSION}

The findings of this literature review suggests that empowerment is a widely-used concept that has a major influence on health care, and highlights the multiple attempts to design empowerment strategies within education programs, operationalize the concept and develop tools and enable the measurement of empowerment in all its dimensions.
Based on the different definitions and dimensions analyzed by this review, it can be concluded that empowerment in the context of patients with chronic disease is a concept employed at individual level, which is regarded as both a process and an outcome. Empowerment may be seen as an enabling process whereby health care professionals collaborate with patients to help them acquire knowledge and resources and whose outcome is a patient with greater ability to exercise control, manage his/her condition and to make informed decisions.

Empowerment demands a paradigm shift in health care: the challenge lies in how to incorporate the concept into health care practice. Understanding strategies for increasing patient health literacy is not enough to foster empowerment. If the end goal is behavioral change, it is necessary to incorporate motivational strategies.

It is important to highlight the importance of developing patient empowerment measures that capture the above dimensions while encompassing the three levels of the concept: at a basic level, during the process, and at the outcome level. However, this analysis illustrates once again the complexities involved in developing an overarching generic measure translated into different languages that enables comparison between empowerment strategies at international level.

\section{RESUMO}

Objetivo: Analisar as definições e as dimensões do conceito de empoderamento. Identificar os pontos fortes e fracos dos instrumentos de medição de empoderamento a partir do seu modelo conceitual. Método: Revisão integrativa da literatura nas bases de dados MEDLINE e Cumulative Index to Nursing and Allied Health Literature (CINAHL). Resultados: Foram selecionados 29 artigos, 17 definições de empoderamento, sete propostas de dimensões e 10 instrumentos de medição. Empoderamento pode ser concebido como um processo de formação e habilitação em que se transfere o poder de um indivíduo a outro, ou como resultado/produto desse processo; as dimensões refletem indicadores de resultados, tais como a participação na tomada de decisões e assumir o controle; e os indicadores relativos ao processo referem-se à aquisição de conhecimentos e às habilidades de enfrentamento. Dos instrumentos analisados, seis têm maior robustez. Conclusão: Propor uma definição de empoderamento que possa ajudar a melhorar a compreensão do termo e, assim, operacionalizá-lo.

\section{DESCRITORES}

Participação do Paciente; Poder; Autoeficácia; Tomada de Decisões; Autonomia Pessoal; Revisão.

\section{RESUMEN}

Objetivo: Analizar definiciones y dimensiones de empoderamiento. Identificar fortalezas y debilidades de los instrumentos de medida de empoderamiento respecto al modelo conceptual. Método: Revisión integrativa de la literatura en las bases de datos MEDLINE y Cumulative Index to Nursing and Allied Health Literature (CINAHL). Resultados: Fueram seleccionados 29 artículos . Se identificaron 17 definiciones, 7 propuestas de dimensiones y 10 instrumentos de medida. Empoderamiento puede ser un proceso de capacitación o habilitación en el que se transfiere el poder de un individuo a otro, o bien un resultado producto de ese proceso. Las dimensiones reflejan indicadores de resultados como son la participación en la toma de decisiones y tomar el control, e indicadores relativos al proceso como son la adquisición de conocimientos y las habilidades de afrontamiento. De los instrumentos analizados seis son los instrumentos que presentan mayor robustez. Conclusión: Se propone una definición de empoderamiento que puede ayudar a mejorar la comprensión del término y por lo tanto a operacionalizarlo.

\section{DESCRIPTORES}

Participación del Paciente; Poder; Autoeficacia; Toma de Decisiones, Autonomía Personal; Revisión.

\section{REFERENCES}

1. World Health Organization. Regional Office for Europe. Health 2020 policy framework and strategy document [Internet]. Geneva: WHO; 2012 [cited 2015 Feb. 28]. Available from: http://www.euro.who.int/_data/assets/pdf_file/0020/170093/RC62wd08-Eng.pdf

2. Barr PJ, Scholl I, Bravo P, Faber MJ, Elwyn G, McAllister M. Assessment of patient empowerment: a systematic review of measures. PLoS One. 2015;10(5):e0126553. 
3. Camerini A-L. Health Literacy and Patient Empowerment: Separating Con-joined Twins in the Context of Chronic Low Back Pain. PLoS One. 2015;10(2):e0118032.

4. Fumagalli L, Radaelli G, Emanuele L, Bertele' P, Masella C. Patient Empowerment and its neighbours: Clarifying the boundaries and their mutual relationships. Health Policy. 2015;119(3):384-94.

5. Wang R, Hsu H, Lee Y, Shin S, Lin KD, An LW. Patient empowerment interacts with health literacy to associate with subsequent self-management behaviors in patients with type 2 diabetes: a prospective study in Taiwan. Patient Educ Couns. 2016. pii: S07383991(16)30153-7. [Epub ahead of print]

6. Valderas J, Ferrer M, Mendivil J, Garin O, Rajmil L, Herdman M, et al. Development of EMPRO: A tool for the standardized assessment of patient-reported outcome measures. Value Heal. 2008;11(4):700-8.

7. Aujoulat I, D'Hoore W, Deccache A. Patient empowerment in theory and practice: polysemy or cacophony? Patient Educ Couns. 2007;66(1):13-20.

8. McAllister M, Dunn G, Payne K, Davies L, Todd C. Patient empowerment: the need to consider it as a measurable patient-reported outcome for chronic conditions. BMC Heal Serv Res. 2012;12:157.

9. Small N, Bower P, Chew-Graham C, Whalley D, Protheroe J. Patient empowerment in long-term conditions: development and preliminary testing of a new measure. BMC Heal Serv Res. 2013;13:263.

10. Anderson RM, Funnell MM. Patient empowerment: myths and misconceptions. Patient Educ Couns. 2010;79(3):277-82.

11. Aslani P. Patient empowerment and informed decision-making. Int J Pharm Pract. 2013;21(6):347-8.

12. Bann CM, Sirois FM, Walsh EG. Provider support in complementary and alternative medicine: exploring the role of patient empowerment. J Altern Complement Med. 2010;16(7):745-52.

13. Bulsara C, Styles I, Ward AM, Bulsara M. The psychometrics of developing the patient empowerment scale. J Psychosoc Oncol. 2006;24(1):1-16.

14. Fotoukian Z, Shahboulaghi FM, Khoshknab MF, Mohammadi E. Concept analysis of empowerment in old people with chronic diseases using a hybrid model. Asian Nurs Res. 2014;8(2):118-27.

15. Fumagalli L, Radaelli G, Emanuele L, Bertele' P, Masella C. Patient empowerment and its neighbours: clarifying the boundaries and their mutual relationships. Health Policy. 2015;119(3):384-94.

16. Gibson C. A concept analysis of empowerment. J Adv Nurs. 1991;16(3):354-61.

17. Jerofke TA. Concept analysis of empowerment from survivor and nurse perspectives within the context of cancer survivorship. Res Theory Nurs Pr. 2013;27(3):157-72.

18. McWilliam CL. Patients, persons or partners? Involving those with chronic disease in their care. Chronic Illn. 2009;5(4):277-92.

19. O'Cathain A, Goode J, Luff D, Strangleman T, Hanlon G, Greatbatch D. Does NHS direct empower patients? Soc Sci Med. 2005;61(8):1761-71.

20. Rodwell CM. An analysis of the concept of empowerment. J Adv Nurs. 1996;23(2):305-13.

21. Shearer NBC, Cisar N, Greenberg EA. A telephone-delivered empowerment intervention with patients diagnosed with heart failure. Hear Lung. 2007;36(3):159-69.

22. Wentzer HS, Bygholm A. Narratives of empowerment and compliance: studies of communication in online patient support groups. Int J Med Inform. 2013;82(12):E386-94.

23. Boudioni M, McLaren SM, Lister G. Cross-national diagnostic analysis of patient empowerment in England and Greece. Int J Caring Sci. 2012;5(3):246-64

24. Aghili R, Khamseh ME, Malek M, Banikarimi AS, Baradaran HR, Ebrahim Valojerdi A. Development and validation of diabetes empowerment questionnaire in Iranian people with type 2 diabetes. Int Nurs Rev. 2013;60(2):267-73.

25. Ouschan R, Sweeney JC, Johnson LW. Dimensions of patient empowerment: implications for professional services marketing. Heal Mark Q. 2000;18(1-2):99-114.

26. Aujoulat I, Deccache A, Marcolongo R, Bonadiman L. Reconsidering patient empowerment in chronic illness: A critique of models of self-efficacy and bodily control. Soc Sci Med. 2008;66(5):1228-39.

27. Oh HJ, Lee B. The Effect of computer-mediated social support in online communities on patient empowerment and doctor-patient communication. Health Commun. 2012;27(1):30-41.

28. Salmon P, Hall GM. Patient empowerment or the emperor's new clothes. J R Soc Med. 2004;97(2):53-6.

29. Anderson RM, Funnell MM, Fitzgerald JT, Marrero DG. The Diabetes Empowerment Scale: a measure of psychosocial self-efficacy. Diabetes Care. 2000;23(6):739-43

30. Faulkner M. A measure of patient empowerment in hospital environments catering for older people. J Adv Nurs. 2001;34(5):676-86.

31. Hibbard JH, Stockard J, Mahoney ER, Tusler M. Development of the Patient Activation Measure (PAM): conceptualizing and measuring activation in patients and consumers. Heal Serv Res. 2004;39(4 Pt 1):1005-26.

32. Howie JG, Heaney DJ, Maxwell M, Walker JJ. A comparison of a Patient Enablement Instrument (PEI) against two established satisfaction scales as an outcome measure of primary care consultations. Fam Pract. 1998;15(2):165-71.

33. Rogers ES, Chamberlin J, Ellison ML, Crean T. A consumer-constructed scale to measure empowerment among users of mental health services. Psychiatr Serv. 1997;48(8):1042-7. 
34. Seçkin G. Informational and decisional empowerment in online health support communities: initial psychometric validation of the Cyber Info-Decisional Empowerment Scale (CIDES) and preliminary data from administration of the scale. Support Care Cancer. 2011;19(12):2057-61.

35. McAllister M, Wood AM, Dunn G, Shiloh S, Todd C. The Genetic Counseling Outcome Scale: a new patient-reported outcome measure for clinical genetics services. Clin Genet. 2011;79(5):413-24.

36. Pulvirenti M, McMillan J, Lawn S. Empowerment, patient centred care and self-management. Health Expect. 2014;17(3):303-10.

37. Wåhlin I. Empowerment in critical care: a concept analysis. Scand J Caring Sci. 2016 May 10. [Epub ahead of print]

38. Pick S, Sirkin J, Ortega I, Osorio P, Martinez R, Xocolotzin UGM. Escala Para Medir Agencia Personal y Empoderamiento (ESAGE). Interam J Psychol. 2007;41(3):295-304.

39. Christens BD. In search of powerful empowerment. Health Educ Res. 2013;28(3):371-4.

40. Nygårdh A, Malm D, Wikby K, Ahlström G. The experience of empowerment in the patient-staff encounter: the patient's perspective. J Clin Nurs. 2012;21(5-6):897-904.

41. Cattaneo LB, Chapman AR. The process of empowerment: a model for use in research and practice. Am Psychol. 2010;65(7):646-59. 